\title{
Recent advances in understanding biliary atresia [version 1;
}

\section{peer review: 3 approved]}

\author{
Andrew Wehrman (iD1, Orith Waisbourd-Zinman1,2, Rebecca G Wells ${ }^{3}$ \\ ${ }^{1}$ Gastroenterology, Hepatology, and Nutrition, The Children's Hospital of Philadelphia, Philadelphia, PA, 19104, USA \\ ${ }^{2}$ Gastroenterology, Hepatology, and Nutrition, Schneider Children's Medical Center of Israel, Petach-Tiqva, Israel \\ ${ }^{3}$ Medicine and Bioengineering, University of Pennsylvania, Philadelphia, PA, 19104, USA
}

V1 First published: 25 Feb 2019, 8(F1000 Faculty Rev):218
https://doi.org/10.12688/f1000research.16732.1

Latest published: 25 Feb 2019, 8(F1000 Faculty Rev):218

https://doi.org/10.12688/f1000research.16732.1

\begin{abstract}
Biliary atresia (BA) is a neonatal liver disease characterized by progressive obstruction and fibrosis of the extrahepatic biliary tree as well as fibrosis and inflammation of the liver parenchyma. Recent studies found that infants who will go on to develop BA have elevated direct bilirubin levels in the first few days of life, suggesting that the disease starts in utero. The etiology and pathogenesis of BA, however, remain unknown. Here, we discuss recent studies examining potential pathogenetic mechanisms of BA, including genetic susceptibility, involvement of the immune system, and environmental insults such as viruses and toxins, although it is possible that there is not a single etiological agent but rather a large group of injurious insults that result in a final common pathway of extrahepatic bile duct obstruction and liver fibrosis. The management and diagnosis of BA have not advanced significantly in the past decade, but given recent advances in understanding the timing and potential pathogenesis of BA, we are hopeful that the next decade will bring early diagnostics and novel therapeutics.
\end{abstract}

Keywords

bile duct, Kasai, hepatoportoenterostomy, bilirubin

\section{Open Peer Review}

$\begin{array}{ccc}\text { Approval Status } & \checkmark \\ 1 & 2 & 3\end{array}$

version 1

25 Feb 2019

Faculty Reviews are review articles written by the prestigious Members of Faculty Opinions. The articles are commissioned and peer reviewed before publication to ensure that the final, published version is comprehensive and accessible. The reviewers who approved the final version are listed with their names and affiliations.

1. Tatsuo Kuroda, Keio University School of Medicine, Tokyo, Japan

2. Jan B F Hulscher, University Medical Centre Groningen, University of Groningen, Groningen, The Netherlands

3. Mohamed Rela, Dr. Rela Institute \& Medical Centre, National Foundation for Liver Research, Chennai, India

Any comments on the article can be found at the end of the article. 
Corresponding authors: Orith Waisbourd-Zinman (oritwz@gmail.com), Rebecca G Wells (rgwells@pennmedicine.upenn.edu)

Author roles: Wehrman A: Writing - Original Draft Preparation, Writing - Review \& Editing; Waisbourd-Zinman O: Conceptualization, Supervision, Writing - Original Draft Preparation, Writing - Review \& Editing; Wells RG: Conceptualization, Funding Acquisition, Project Administration, Supervision, Writing - Original Draft Preparation, Writing - Review \& Editing

Competing interests: No competing interests were disclosed.

Grant information: This work was supported by the Fred and Suzanne Biesecker Pediatric Liver Center and the National Institute of Diabetes and Digestive and Kidney Diseases (R56 DK119290).

The funders had no role in study design, data collection and analysis, decision to publish, or preparation of the manuscript.

Copyright: @ 2019 Wehrman A et al. This is an open access article distributed under the terms of the Creative Commons Attribution License, which permits unrestricted use, distribution, and reproduction in any medium, provided the original work is properly cited.

How to cite this article: Wehrman A, Waisbourd-Zinman $O$ and Wells RG. Recent advances in understanding biliary atresia [version 1; peer review: 3 approved] F1000Research 2019, 8(F1000 Faculty Rev):218 https://doi.org/10.12688/f1000research.16732.1

First published: 25 Feb 2019, 8(F1000 Faculty Rev):218 https://doi.org/10.12688/f1000research.16732.1 


\section{Introduction}

Biliary atresia (BA) is a fibrotic disease affecting primarily the extrahepatic biliary tree that presents exclusively in infants. Children appear normal at birth but rapidly develop progressive liver fibrosis, bile duct obstruction, and cholestasis over the first several months of life. Surgical management with a Kasai hepatoportoenterostomy (HPE) can relieve the obstruction and, in about $50 \%$ of infants in North America, lead to bile drainage; however, in most children, there is ongoing fibrosis and inflammation in the liver, leading to end-stage liver disease and the need for liver transplant during childhood. There may be geographic differences in the success of HPE, with successful drainage shown as high as $70 \%$ in a Japanese registry, depending on the age at time of surgery ${ }^{2}$. BA remains the leading indication for pediatric liver transplantation, and, to date, no medical interventions have been identified. The etiology of the disease is unknown, adding to the difficulties in studying and developing therapies for BA. Recent data, however, have changed our understanding of the disease. A hypothesis supported by current data proposes that a prenatal environmental insult (toxin or virus) damages the extrahepatic bile duct in a genetically and developmentally susceptible fetus but spares the mother and that injury progresses after birth, leading to immune system activation and possible autoimmunity (Figure 1). This review will discuss literature supporting this hypothesis on the etiology of BA as well as recent studies involving clinical management and prognosis after HPE in BA.

\section{Biliary atresia likely begins in utero}

Fundamental to this hypothesis are recent studies showing that conjugated (or direct) bilirubin is abnormal at birth in children who go on to develop BA. Harpavat et al. studied over 10,000 infants who were screened with fractionated bilirubin in the first 72 hours of life $\mathrm{e}^{3,4}$. Those with abnormal direct or conjugated bilirubin at birth underwent measurement of fractionated bilirubin again 2 weeks later. Of the 13 infants who tested positive on the second screen, two had BA, and no infants with

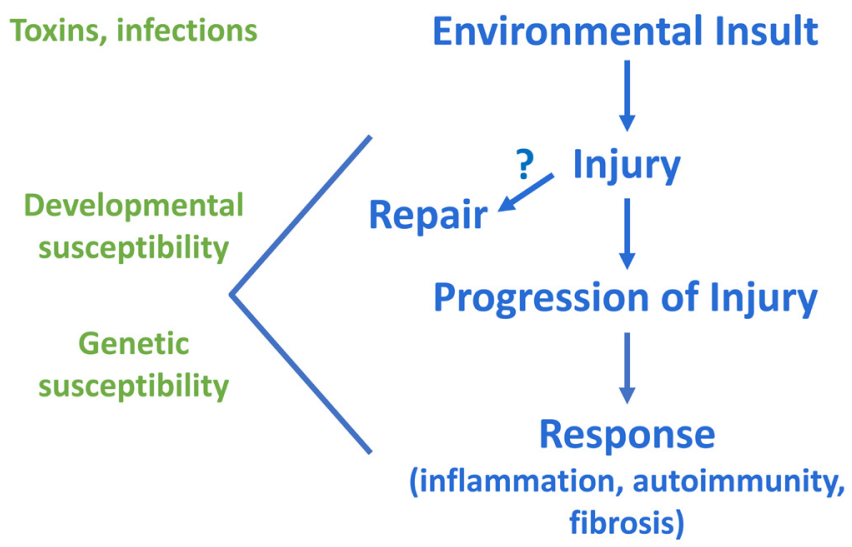

Figure 1. Schematic of hypothesis of biliary atresia etiology. Right side shows potential sequence of events, beginning with a prenatal bile duct injury, in biliary atresia. Left side highlights the potential contribution of developmental and genetic susceptibility to the injury and response.
BA were missed ${ }^{3,4}$. These data and similar studies from the same group provide convincing evidence that the initial injury in BA occurs before birth and suggests that the fetal bile duct is uniquely susceptible to injury and fibrotic sequellae. Understanding the timing of the initial injury in BA will be important in directing future research into factors that lead to injury or repair of the neonatal bile duct; regardless, this study raises the possibility that diagnosis and treatment of newborns (shortly after birth) may be both possible and preferable compared with treatment at the usual time of HPE.

\section{Potential etiologies of biliary atresia}

Epidemiology studies suggest that the cause of BA is environmental ${ }^{5}$, and both infections and environmental toxins have been studied as potential agents causing damage leading to BA. One heavily studied infectious agent is rotavirus. Early postnatal infection of mouse pups with rhesus rotavirus (RRV) leads to a BA-like inflammatory response in the extrahepatic bile duct and has been widely used as a model of BA; however, rotavirus has not been shown to cause human BA, and a recent study showed that the incidence of BA has not changed despite widespread rotavirus vaccination ${ }^{6}$. Cytomegalovirus (CMV) DNA was identified in $60 \%$ of liver biopsies from children with BA in $\mathrm{China}^{7}$, and in a large study of 210 infants with BA in the UK, 9.5\% of infants were CMV IgM-positive at presentation; those who were positive had worse outcomes, including decreased survival with a native liver ${ }^{8}$. CMV may be a trigger for many infants who develop BA; however, validation of the data in additional centers is required.

An isoflavonoid biliary toxin called biliatresone was recently isolated from Australian plants after several large-scale outbreaks of a BA-like disease in newborn livestock born to mothers that grazed on these plants while pregnant ${ }^{9}$. Biliatresone acts a biliary toxin in in vitro organoid models, mouse extrahepatic bile duct explants, and larval zebrafish, providing a proof of concept that toxins can cause selective extrahepatic biliary damage. Biliatresone treatment leads to luminal obstruction and loss of cholangiocyte polarity in mammalian models ${ }^{10}$. It appears to injure cholangiocytes in part through depletion of glutathione, and restoration of glutathione stores with $N$-acetyl-L-cysteine mitigates its toxicity in mouse cholangiocytes and zebrafish ${ }^{10,11}$. Although biliatresone is not ingested by humans and is unlikely to be the cause of human BA, it is useful as a model for studying toxic insults to neonatal bile ducts and pathways of injury and repair in the neonatal bile duct. It is possible that there are similar environmental toxins that lead to human disease; additionally, understanding the mechanisms whereby biliatresone accumulates in the bile ducts may be important in understanding other potential biliary toxins.

The fact that BA does not occur in humans as discrete outbreaks suggests that there is not a single etiological agent but that there may be a large group of etiological agents, potentially including toxins and infectious agents. Identifying common mechanisms of injury and repair may be a better approach to developing therapeutic agents than searching for single etiological agents. 


\section{Genetic susceptibility in biliary atresia}

BA is not a primary genetic disease, although multiple genes that might increase susceptibility to BA have been identified. A genome-wide association study (GWAS) in Chinese infants with BA identified variants in the ADD3 gene; knockdown of ADD3 in zebrafish resulted in intrahepatic biliary abnormalities due to increased hedgehog signaling ${ }^{12,13}$. Variants in GPC1 have also been identified in children with BA. Knockdown of GPC1 in zebrafish led to biliary abnormalities, and partial recovery was achieved using a hedgehog antagonist ${ }^{14}$. A recent GWAS in children with both isolated BA and BA splenic malformation syndrome (BASM) identified the candidate gene EFEMP1, which encodes the extracellular matrix (ECM) protein fibulin-3 and may be important in both the structure and repair of the ECM ${ }^{15}$. Preliminary work via whole exome sequencing of family trios has identified a variant in the primary cilia protein PKD1L1, suggesting that primary cilia may also play a role in the susceptibility of the extrahepatic bile duct to injury ${ }^{16}$. Overall, there appear to be multiple gene defects associated with BA, but all appear to increase susceptibility or modify the phenotype rather than being primarily responsible for injury.

The lack of an identifiable genetic cause of BA has led to the hypothesis that maternal microchimerism (postzygotic somatic mutation) may be part of the etiology ${ }^{17,18}$. Although a recent study has shown no evidence of maternal microchimerism in lymph nodes ${ }^{19}$, additional studies would be required to both demonstrate the presence of microchimerism in BA and show that it has a causal role in the disease.

\section{The role of inflammation and autoimmunity}

Regardless of the initial injury in BA, a hallmark of the disease is significant inflammation and fibrosis of both the liver and ducts. Abnormalities in innate immunity, cellular immunity, and antibody-mediated immunity have been identified in both human samples and mouse models ${ }^{5,16,20,21}$. Interleukin 17a (IL17a) has recently been shown to promote macrophage recruitment through chemokine signaling in the RRV mouse model and may be important in the progression of the liver and duct injury ${ }^{22}$. RRV-infected mice have increased hepatic IL17a mRNA and IL17a antibody treatment mitigated injury ${ }^{23}$, and children with BA had a higher load of IL17a-positive cells in liver samples compared with both normal and cholestatic controls ${ }^{22}$. There is indirect evidence that autoimmunity plays a role in the pathogenesis of $\mathrm{BA}^{16}$. In the RRV model of $\mathrm{BA}$, adoptive transfer of $\mathrm{T}$ cells from a mouse with $\mathrm{BA}$ to a $\mathrm{T}$ cell-deficient mouse produces bile duct injury ${ }^{24}$. Also, in the RRV mouse model, $\mathrm{B}$ cell-deficient mice do not develop BA and adoptive transfer of B cells into RRV-infected B cell-deficient mice leads to biliary epithelial damage and T-cell activation, likely mediated through cytokines ${ }^{25}$. Notably, anti-inflammatory treatments, including steroids ${ }^{26}$ and intravenous immunoglobulin (IVIG) ${ }^{27}$, given at the time of HPE, have all failed to change the progression of fibrosis and inflammation.

\section{Screening and diagnosis}

The timing and accuracy of BA diagnosis are highly clinically relevant issues given that older age ( $>30$ days) and greater degree of fibrosis at the time of HPE are associated with increased need for liver transplant ${ }^{28-30}$. Stool cards are widely used in certain countries and have been shown to decrease the number of late referrals for evaluation of symptomatic infants and to decrease the age at $\mathrm{HPE}^{31}$. Screening newborns for elevated direct or conjugated bilirubin, as discussed above, offers the potential to identify asymptomatic babies very early in the course of the disease but has relatively low specificity and has not yet been implemented widely ${ }^{3,4}$.

The diagnosis of BA in a jaundiced infant can be difficult. An intraoperative cholangiogram remains the gold standard, and frequently a liver biopsy is obtained to aid in diagnosis. A large study of 227 liver biopsies in infants with neonatal cholestasis defined significant features suggestive of BA, including bile plugs, moderate to marked ductular reaction, and portal stromal edema; however, the overall sensitivity and specificity of needle biopsy in the diagnosis of BA were $88.4 \%$ and $92.7 \%$, respectively. No findings on liver biopsy were predictive of successful drainage ${ }^{28}$. A hepatobiliary iminodiacetic acid (HIDA) scan is used in some centers to assess bile passage to the gut, whereas in other centers this is not considered necessary in the setting of a suggestive liver biopsy. Endoscopic retrograde cholangiopancreatography ${ }^{32}$ and transient elastography ${ }^{33}$ are being investigated for the diagnosis of BA, but the use of these imaging methods is not widespread. A large proteomics study identified increased matrix metalloproteinase 7 (MMP-7) (expressed by cholangiocytes and released upon injury) in infants with BA as a potential biomarker for $\mathrm{BA}^{34}$. Children with BA have been shown to have elevated serum MMP-7 compared with both healthy and cholestatic controls, and the level of MMP-7 correlated with fibrosis stage $\mathrm{e}^{35}$. MMP-7 has been shown to have a high sensitivity and specificity (98.67\% and $95 \%$, respectively) when used to distinguish BA from other causes of neonatal cholestasis ${ }^{36}$. This work has promising implications as a non-invasive biomarker to aid in the diagnosis of BA in the future but is not yet used clinically.

\section{Clinical management}

The management of BA has not changed significantly in the past decade. Most children with diagnosed BA undergo HPE, whereby the atretic extrahepatic bile duct is resected to the level of the porta hepatis and drained via a roux-en-Y loop of jejunum $^{37}$. HPE is successful in about $50 \%$ of infants, and success (indicating bile drainage) is defined as total bilirubin of less than $2 \mathrm{mg} / \mathrm{dL}$ at 3 months post-HPE. Children with total bilirubin of more than $2 \mathrm{mg} / \mathrm{dL}$ are more likely to have complications of liver disease, including ascites, thrombocytopenia, and decreased survival with native liver, compared with children with adequate drainage ${ }^{1}$. Bile drainage after HPE, though necessary for transplant-free survival, is not curative, and up to $66 \%$ of children with successful HPE will still have ongoing liver fibrosis and portal hypertension ${ }^{38}$. Thus far, no post-HPE adjuvant therapy has been shown to change outcomes in BA. Several trials showed that prednisone treatment after HPE did not promote improved bile drainage and caused significant adverse effects ${ }^{26,39,40}$. Another trial showed that IVIG administration was similarly ineffective at promoting bile drainage post-HPE ${ }^{27}$. Supportive therapy to ensure adequate nutri- 
tion and supplementation with fat-soluble vitamins remain the mainstay of therapy. Ursodeoxycholic acid is given in the vast majority of the centers, and most centers also prescribe prophylactic antibiotics because of the risk of cholangitis in the first 6 to 12 months of life. All children with BA are at risk for neurodevelopmental delays, but those with unsuccessful HPE have four times the risk of both mental/cognitive/language delays and physical/motor delays ${ }^{41}$. BA remains the leading indication for liver transplant in pediatric recipients, accounting for $32.3 \%$ of pediatric liver transplants in $2016^{42}$.

\section{Conclusions and future directions}

Recently, there has been significant progress in understanding the time course of BA and range of potential etiologies. Solid evidence suggests that a prenatal insult, either toxic or infectious, causes injury in a genetically susceptible fetus, leading to progressive fibro-inflammatory damage to the extrahepatic bile duct and associated immune and autoimmune dysfunction.
Current therapies for BA all begin at the time of HPE, which may be too late to significantly change the progression of the disease. New studies showing that asymptomatic infants who will go on to develop BA can be identified weeks to months earlier than the usual time of HPE raise the possibility that the disease can be mitigated before significant damage occurs and potentially cured. Future research and clinical efforts should focus on early diagnosis and on studying the effects of therapeutic agents started within the first few weeks of life.

\section{Grant information}

This work was supported by the Fred and Suzanne Biesecker Pediatric Liver Center and the National Institute of Diabetes and Digestive and Kidney Diseases (R56 DK119290).

The funders had no role in study design, data collection and analysis, decision to publish, or preparation of the manuscript.
1. F Shneider BL, Magee JC, Karpen SJ, et al.: Total Serum Bilirubin within 3 Months of Hepatoportoenterostomy Predicts Short-Term Outcomes in Biliary Atresia. J Pediatr. 2016; 170: 211-7.e1-2. Atresia. J Pediatr. 2016; 170: 211-7.e1-2.
PubMed Abstract | Publisher Full Text | Free Full Text | F1000 Recommendation

2. F Nio M: Japanese Biliary Atresia Registry. Pediatr Surg Int. 2017; 33(12): 1319-25.

PubMed Abstract | Publisher Full Text | F1000 Recommendation

3. Harpavat S, Garcia-Prats JA, Shneider BL: Newborn Bilirubin Screening for Biliary Atresia. N Engl J Med. 2016; 375(6): 605-6. PubMed Abstract | Publisher Full Text

4. F Harpavat S, Ramraj R, Finegold MJ, et al:: Newborn Direct or Conjugated Bilirubin Measurements As a Potential Screen for Biliary Atresia. J Pediatr Gastroenterol Nutr. 2016; 62(6): 799-803. PubMed Abstract | Publisher Full Text | F1000 Recommendation

5. $\quad \mathrm{F}$ Kilgore A, Mack CL: Update on investigations pertaining to the pathogenesis of biliary atresia. Pediatr Surg Int. 2017; 33(12): 1233-41. PubMed Abstract | Publisher Full Text | Free Full Text | F1000 Recommendation

6. F Danial E, Fleck-Derderian S, Rosenthal P: Has Rotavirus Vaccination Decreased the Prevalence of Biliary Atresia? J Clin Gastroenterol. 2018. PubMed Abstract | Publisher Full Text | F1000 Recommendation

7. $\mathrm{Xu} \mathrm{Y,} \mathrm{Yu} \mathrm{J,} \mathrm{Zhang} \mathrm{R,} \mathrm{et} \mathrm{al.:} \mathrm{The} \mathrm{perinatal} \mathrm{infection} \mathrm{of} \mathrm{cytomegalovirus} \mathrm{is} \mathrm{an}$ important etiology for biliary atresia in China. Clin Pediatr (Phila). 2012; 51(2): 109-13.

PubMed Abstract | Publisher Full Text

8. Zani A, Quaglia A, Hadzić N, et al:: Cytomegalovirus-associated biliary atresia: An aetiological and prognostic subgroup. J Pediatr Surg. 2015; 50(10): 1739-45. PubMed Abstract | Publisher Full Text

9. Lorent K, Gong W, Koo KA, et al.: Identification of a plant isoflavonoid that causes biliary atresia. Sci Transl Med. 2015; 7(286): 286ra67. PubMed Abstract | Publisher Full Text | Free Full Text

10. Waisbourd-Zinman $\mathrm{O}$, Koh H, Tsai S, et al:: The toxin biliatresone causes mouse extrahepatic cholangiocyte damage and fibrosis through decreased glutathione and SOX17. Hepatology. 2016; 64(3): 880-93. PubMed Abstract | Publisher Full Text | Free Full Text

11. Zhao X, Lorent $\mathrm{K}$, Wilkins $\mathrm{BJ}$, et al:: Glutathione antioxidant pathway activity and reserve determine toxicity and specificity of the biliary toxin biliatresone in zebrafish. Hepatology. 2016; 64(3): 894-907.

PubMed Abstract | Publisher Full Text | Free Full Text

12. Cheng G, Tang CS, Wong $\mathrm{EH}$, et al.: Common genetic variants regulating ADD3 gene expression alter biliary atresia risk. $J$ Hepatol. 2013; 59(6): 1285-91. PubMed Abstract | Publisher Full Text

13. Tang V, Cofer ZC, Cui S, et al.: Loss of a Candidate Biliary Atresia Susceptibility Gene, add3a, Causes Biliary Developmental Defects in Zebrafish. J Pediatr Gastroenterol Nutr. 2016; 63(5): 524-30. PubMed Abstract | Publisher Full Text | Free Full Text
14. Cui S, Leyva-Vega M, Tsai EA, et al:: Evidence from human and zebrafish that GPC1 is a biliary atresia susceptibility gene. Gastroenterology. 2013; 144(5): 1107-1115.e3.

PubMed Abstract | Publisher Full Text | Free Full Text

15. Chen $\mathrm{Y}$, Gilbert MA, Grochowski CM, et al:: A genome-wide association study identifies a susceptibility locus for biliary atresia on $2 p 16.1$ within the gene EFEMP1. PLoS Genet. 2018; 14(8): e1007532. PubMed Abstract | Publisher Full Text | Free Full Text

16. Bezerra JA, Wells RG, Mack CL, et al: BILIARY ATRESIA: Clinical and Research Challenges for the $21^{\text {st }}$ Century. Hepatology. 2018; 68(3): 1163-1173. PubMed Abstract | Publisher Full Text | Free Full Text

17. Fabre A, Roman C, Roquelaure B: Somatic mutation, a cause of biliary atresia: A hypothesis. Med Hypotheses. 2017; 102: 91-3. PubMed Abstract | Publisher Full Text

18. Suskind DL, Rosenthal P, Heyman MB, et al:: Maternal microchimerism in the livers of patients with biliary atresia. BMC Gastroenterol. 2004; 4: 14 PubMed Abstract | Publisher Full Text | Free Full Text

19. Engelmann C, Maelzer M, Kreyenberg H: Absence of Maternal Microchimerism in Regional Lymph Nodes of Children With Biliary Atresia. $J$ Pediatr Gastroenterol Nutr. 2016; 62(6): 804-7. PubMed Abstract | Publisher Full Text

20. F Yang L, Mizuochi T, Shivakumar $\mathrm{P}$, et al.: Regulation of epithelial injury and bile duct obstruction by NLRP3, IL-1R1 in experimental biliary atresia. J Hepatol. 2018; 69(5): 1136-44.

PubMed Abstract | Publisher Full Text | Free Full Text | F1000 Recommendation

21. Hill R, Quaglia A, Hussain M, et al.: Th-17 cells infiltrate the liver in human biliary atresia and are related to surgical outcome. J Pediatr Surg. 2015; 50(8): 1297-303.

PubMed Abstract | Publisher Full Text

22. F Lages CS, Simmons J, Maddox A, et al.: The dendritic cell-T helper 17macrophage axis controls cholangiocyte injury and disease progression in murine and human biliary atresia. Hepatology. 2017; 65(1): 174-88. PubMed Abstract | Publisher Full Text | Free Full Text | F1000 Recommendation

23. Klemann C, Schröder A, Dreier A, et al:: Interleukin 17, Produced by $\gamma \delta$ T Cells, Contributes to Hepatic Inflammation in a Mouse Model of Biliary Atresia and Is Increased in Livers of Patients. Gastroenterology. 2016; 150(1): 229-241.e5. PubMed Abstract | Publisher Full Text

24. Mack CL, Tucker RM, Lu BR, et al.: Cellular and humoral autoimmunity directed at bile duct epithelia in murine biliary atresia. Hepatology. 2006; 44(5): 1231-9. PubMed Abstract | Publisher Full Text | Free Full Text

25. F Bednarek J, Traxinger B, Brigham D, et al.: Cytokine-Producing B Cells Promote Immune-Mediated Bile Duct Injury in Murine Biliary Atresia. Hepatology. 2018; 68(5): 1890-904. PubMed Abstract | Publisher Full Text | Free Full Text | F1000 Recommendation

26. F Bezerra JA, Spino C, Magee JC, et al:: Use of corticosteroids after 
hepatoportoenterostomy for bile drainage in infants with biliary atresia: the START randomized clinical trial. JAMA. 2014; 311(17): 1750-9. PubMed Abstract | Publisher Full Text | Free Full Text | F1000 Recommendation

27. Sokol R, Spino C, Moore J, et al.: Intravenous Immunoglobulin (IVIG) Following Portoenterostomy in Infants with Biliary Atresia: a Phase 1/2A Trial. In: AASLD The Liver Meeting. Boston, MA: AASLD; 2016.

28. F Russo P, Magee JC, Anders RA, et al: Key Histopathologic Features of Liver Biopsies That Distinguish Biliary Atresia From Other Causes of Infantile Cholestasis and Their Correlation With Outcome: A Multicenter Study. Am J Surg Pathol. 2016; 40(12): 1601-15.

PubMed Abstract | Publisher Full Text | Free Full Text | F1000 Recommendation

29. Schreiber RA, Barker CC, Roberts EA, et al.: Biliary atresia: the Canadian experience. J Pediatr. 2007; 151(6): 659-65, 665.e1. PubMed Abstract | Publisher Full Text

30. Serinet $\mathrm{MO}$, Wildhaber $\mathrm{BE}$, Broué $\mathrm{P}$, et al:: Impact of age at Kasai operation on its results in late childhood and adolescence: a rational basis for biliary atresia screening. Pediatrics. 2009; 123(5): 1280-6. PubMed Abstract | Publisher Full Text

31. $\quad F$ Tseng JJ, Lai MS, Lin MC, et al.: Stool color card screening for biliary atresia. Pediatrics. 2011; 128(5): e1209-e1215.

PubMed Abstract | Publisher Full Text | F1000 Recommendation

32. Negm AA, Petersen C, Markowski A, et al.: The Role of Endoscopic Retrograde Cholangiopancreatography in the Diagnosis of Biliary Atresia: 14 Years Experience. Eur J Pediatr Surg. 2018; 28(3): 261-7. PubMed Abstract | Publisher Full Text

33. Wu JF, Lee CS, Lin WH, et al:: Transient elastography is useful in diagnosing biliary atresia and predicting prognosis after hepatoportoenterostomy. Hepatology. 2018; 68(2): 616-24.

PubMed Abstract | Publisher Full Text

34. F Lertudomphonwanit C, Mourya R, Fei L, et al.: Large-scale proteomics identifies MMP-7 as a sentinel of epithelial injury and of biliary atresia. $\mathrm{Sci}$ Transl Med. 2017; 9(417): pii: eaan8462.

PubMed Abstract | Publisher Full Text | Free Full Text | F1000 Recommendation

35. Kerola A, Lampela H, Lohi J, et al.: Increased MMP-7 expression in biliary epithelium and serum underpins native liver fibrosis after successful portoenterostomy in biliary atresia. J Pathol Clin Res. 2016; 2(3): 187-98. PubMed Abstract | Publisher Full Text | Free Full Text

36. F Yang L, Zhou Y, Xu PP, et al.: Diagnostic Accuracy of Serum Matrix Metalloproteinase-7 for Biliary Atresia. Hepatology. 2018; 68(6): 2069-77. PubMed Abstract | Publisher Full Text | F1000 Recommendation

37. Kasai $M$, Suzuki $H$, Ohashi $E$, et al:: Technique and results of operative management of biliary atresia. World J Surg. 1978; 2(5): 571-9. PubMed Abstract | Publisher Full Text

38. Shneider BL, Abel B, Haber B, et al:: Portal hypertension in children and young adults with biliary atresia. J Pediatr Gastroenterol Nutr. 2012; 55(5): 567-73. PubMed Abstract | Publisher Full Text | Free Full Text

39. F Tyraskis A, Parsons C, Davenport M: Glucocorticosteroids for infants with biliary atresia following Kasai portoenterostomy. Cochrane Database Syst Rev. 2018; 5: CD008735.

PubMed Abstract | Publisher Full Text | F1000 Recommendation

40. F Alonso EM, Ye W, Hawthorne K, et al:: Impact of Steroid Therapy on Early Growth in Infants with Biliary Atresia: The Multicenter Steroids in Biliary Atresia Randomized Trial. J Pediatr. 2018; 202: 179-185.e4. PubMed Abstract | Publisher Full Text | Free Full Text | F1000 Recommendation

41. F Ng VL, Sorensen LG, Alonso EM, et al:: Neurodevelopmental Outcome of Young Children with Biliary Atresia and Native Liver: Results from the ChiLDReN Study. J Pediatr. 2018; 196: 139-147.e3. PubMed Abstract | Publisher Full Text | Free Full Text | F1000 Recommendation

42. Kim WR, Lake JR, Smith JM, et al.: OPTN/SRTR 2016 Annual Data Report: Liver. Am J Transplant. 2018; 18 Suppl 1: 172-253.

PubMed Abstract | Publisher Full Text 


\section{Open Peer Review}

\section{Current Peer Review Status:}

\section{Editorial Note on the Review Process}

Faculty Reviews are review articles written by the prestigious Members of Faculty Opinions. The articles are commissioned and peer reviewed before publication to ensure that the final, published version is comprehensive and accessible. The reviewers who approved the final version are listed with their names and affiliations.

\section{The reviewers who approved this article are:}

\section{Version 1}

\section{Mohamed Rela}

Dr. Rela Institute \& Medical Centre, National Foundation for Liver Research, Chennai, India

Competing Interests: No competing interests were disclosed.

\section{Jan B F Hulscher}

Department of Surgery, Division of Pediatric Surgery, University Medical Centre Groningen, University of Groningen, Groningen, The Netherlands

Competing Interests: No competing interests were disclosed.

\section{Tatsuo Kuroda}

Department of Pediatric Surgery, Keio University School of Medicine, Tokyo, Japan

Competing Interests: No competing interests were disclosed.

The benefits of publishing with F1000Research:

- Your article is published within days, with no editorial bias

- You can publish traditional articles, null/negative results, case reports, data notes and more

- The peer review process is transparent and collaborative

- Your article is indexed in PubMed after passing peer review

- Dedicated customer support at every stage

For pre-submission enquiries, contact research@f1000.com 